St. Catherine University

From the SelectedWorks of Hui Wilcox

2011

\title{
Movement in spaces of liminality: Chinese Dance and Immigrant Identities
}

Hui Wilcox, St. Catherine University 
This article was downloaded by: [College of St Catherine]

On: 19 March 2011

Access details: Access Details: [subscription number 932657354]

Publisher Routledge

Informa Ltd Registered in England and Wales Registered Number: 1072954 Registered office: Mortimer House, 3741 Mortimer Street, London W1T 3JH, UK

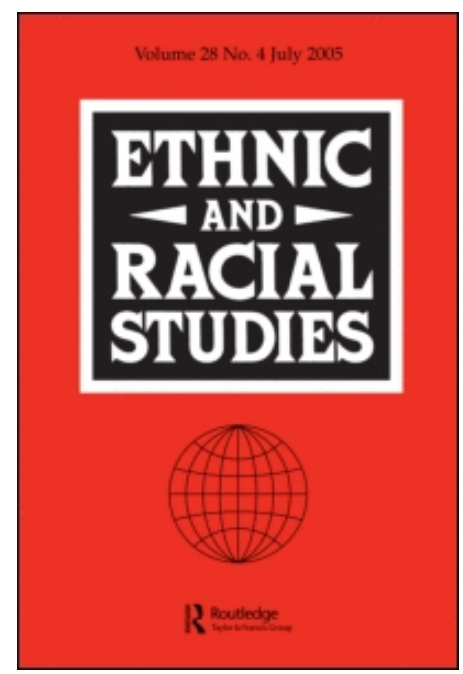

\section{Ethnic and Racial Studies}

Publication details, including instructions for authors and subscription information:

http://www.informaworld.com/smpp/title content=t713685087

\section{Movement in spaces of liminality: Chinese dance and immigrant identities}

Hui Wilcox

Online publication date: 06 January 2011

To cite this Article Wilcox, Hui(2011) 'Movement in spaces of liminality: Chinese dance and immigrant identities', Ethnic and Racial Studies, 34: 2, 314 - 332

To link to this Article: DOI: $10.1080 / 01419870.2010 .528439$

URL: http://dx.doi.org/10.1080/01419870.2010.528439

PLEASE SCROLL DOWN FOR ARTICLE

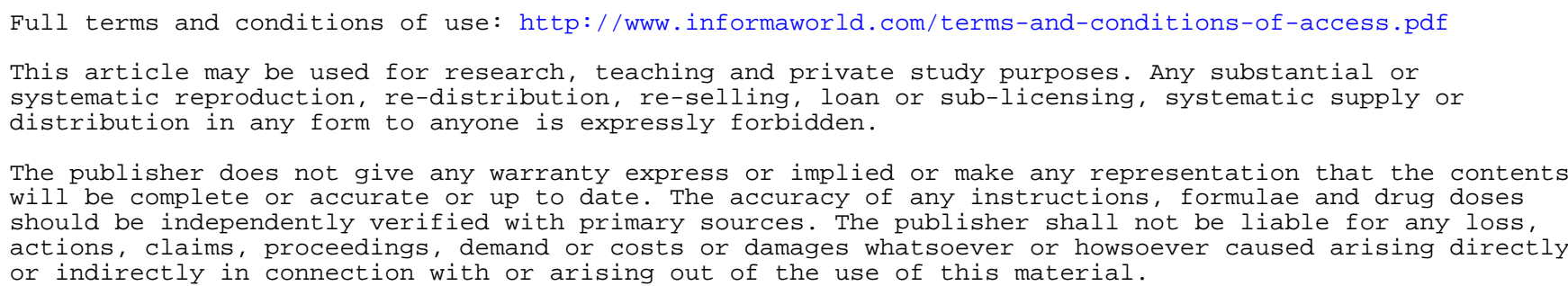




\title{
Movement in spaces of liminality: Chinese dance and immigrant identities
}

\author{
Hui Wilcox
}

(First submission February 2009; First published November 2010)

\begin{abstract}
This paper explores the roles of immigrant dance in ethnic construction. It is based on participant observation and in-depth interviews with a Chinese dance organization in the US Midwest. Chinese dance in the US, a transnational cultural practice, solidifies a sense of belonging among Chinese immigrants. As these immigrants make sense of what it means to be Chinese and to do Chinese dance in contemporary American society, they reinvent their collective identity while holding on to primordial understandings of ethnicity rooted in the constructed ideas of ancestry and homeland. A case study of the ethnic construction theory, this research sheds light on the paradox of embodied immigrant identities: they are constructed through cultural practices and yet often understood as primordial, transnational and yet necessarily place-bound.
\end{abstract}

Keywords: Ethnic identity; Chinese diaspora; performance; dance; immigrant communities; transnational cultural practice.

Dance is movement in a liminal space. So is migration: travelling across the vastness of oceans and continents, carefully choreographed or hastily improvised; travelling that defies borders and lacks final destinations. A transnational social space is as liminal as a dance space: they are in-between spaces pregnant with ambiguities and possibilities.

The dance of migration entails human movement and contact, which transform space, time and other dimensions of our worlds large and small - the globe, nations, communities, and selves. (Author's reflection, 2009) 
In Midwest City, ${ }^{1}$ dance makes its way into many events of the local Chinese immigrant community: celebrations of Chinese New Year and Mid-autumn Festival, annual banquets of immigrant organizations and fundraisers like the Sichuan earthquake relief efforts in 2008. Dance productions draw the biggest, most visible Chinese crowds in this US Midwestern metropolitan area where Chinese immigrants numbered 17,000 in 2000 and are dispersed in various suburbs.

'Chinese dance' in the cultural schemata of recent Chinese immigrants is comprised of three types of choreographies: 'classical Chinese dance' (gudian wu) constructed from images in ancient frescos, sculptures and other historical records, 'Chinese folk dance' (minjian $w u$ ) originating from folk movement traditions of Han, the dominant ethnic group in China, and 'Chinese ethnic dance' (minzu $w u$ ) appropriated from the movement traditions of various ethnic minority groups in China. All three types are heavily influenced by Western ballet aesthetics such as pointed feet and extended body lines. The development of this classical/folk/ethnic typology and these hybrid dance styles is part and parcel of the institutionalization of 'Chinese dance' by the Chinese state since the 1950s.

In the last three decades, Chinese dance has become a transnational phenomenon. One cannot underestimate the amount of resources devoted to Chinese dance by the Chinese state within and beyond its border, and by overseas Chinese in their host societies. Many Chinese immigrants watched in awe as the 2008 Beijing Olympic Games' spectacular opening ceremony unfolded on $\mathrm{TV}^{2}$ This multi-million dollar operation was in essence a carefully choreographed and meticulously rehearsed dance performance involving 14,000 performers. In 2009 and 2010, the Chinese government sponsored song and dance troupes to tour North America, South America, Europe and Southeast Asia during the Chinese New Year season, reportedly drawing large crowds of overseas Chinese (China Tribune, 29 January 2010). In the United States, Chinese dance organizations, ranging from professional troupes to community dance schools, exist in many urban centres such as Dallas, Houston, Los Angeles, Minneapolis/St. Paul, New York, Phoenix, San Francisco and Seattle.

This paper explores the sociological implications of Chinese dance practised by recent Chinese immigrants. Based on ten years of participant observation of Chinese Dance Group ${ }^{3}$ in Midwest City and in-depth interviews of CDG participants, my research unpacks the social meanings of Chinese dance and explores how Chinese dance shapes identities and communities among Chinese immigrants. These identities and communities are both transnational and place-bound, premised on both primordial needs for belonging and ever-shifting circumstances in immigrants' sending and receiving societies. This 
research, with attention to embodied transnational cultural practice, offers a case study illuminating and extending theories of ethnic construction. It also demonstrates that explicit attention to embodied practices such as dance leads to fresh insights for the study of migration and transnationalism (Ram 2000a, 2005).

\section{Ethnic construction and dance in transnational social spaces}

This ethnographic case study is informed by theories of ethnicity, migration studies with a focus on transnationalism and interdisciplinary scholarship on dance and performance. Cornell and Hartmann (2007) identify three prominent theories of ethnicity: primordialism, circumstantialism and social constructionism. According to primordialism, ethnicity is deep-rooted, irrational and cannot be easily dispensed with or changed. Circumstantialism, by contrast, conceptualizes ethnicity as a utilitarian invention driven by economic and political interests (Sollors 1989). Constructionism sheds light on the intricate negotiations between primordial and circumstantial aspects of ethnic identities (Cornell and Hartmann 2007). According to this model, ethnic construction involves both internal, primordial identification hinged on kinship and external contexts such as immigration laws and race or ethnic relations (Nagel 1994; Cerulo 1997). While ethnic identities are deeply emotive, they are anything but immutable. In fact, seemingly primordial signifiers of ethnicity such as languages, beliefs and ancestral origins are often socially constructed: hence the term 'constructed primordials' (Appadurai 1996).

The constructionist model concerns both the content of ethnicity and ethnic boundaries (Nagel 1994; Sanders 2002). Ethnic content refers to an ethnic group's cultural characteristics, including but not limited to history, language, food and symbols. Ethnic boundaries manifest as the distinction of us and them, established through intra- and interethnic interactions (Waters 1990; Sanders 2002). Members and groups of an ethnically diverse society constantly engage in boundary-making activities, such as naming their own identity ('We are Chinese'), engaging in unique cultural practices (Chinese dance) and emphasizing the difference between their own culture and that of other groups ('Chinese dance is different from Western dance'). Together, these intertwining discursive and embodied practices constitute the ethnic identity of being Chinese in the United States.

Scholars in both ethnic studies and migration studies have recently been linking ethnic formation with transnational social spaces, shifting away from the exclusive focus on the receiving society's internal dynamics regarding immigration and assimilation (Levitt 2001; Levitt and Waters 2002; Kivisto 2001, 2003). Transnational 
social spaces are dynamic social spheres consisting of immigrant kinship ties, circulation of goods/ideas/people and immigrant communities, all of which straddle nations (Faist 2000a, 2000b; Kivisto 2003; Levitt, DeWind and Vertovec 2003). Kibria (2002), examining the experience of second-generation Chinese and Korean Americans in Los Angeles and Boston from 1992 to 1997, suggested that they have not formed strong transnational ties. However, researchers such as Featherstone (1996) and Louie (2002) projected that, with China's ascending power in the context of globalization, transnationalism could take on more significance in Chinese immigrant communities. This projection finds support in my research of recent professional immigrants from China at the beginning of the twenty-first century. These immigrants' lives are increasingly transnational thanks to their access to technologies and their middle-class status (Ong 1999). One cannot overlook such a reality while studying how these immigrants construct communities and identities.

Although transnationalism is not new (Foner 1997), the speed and myriad ways of contemporary transnational exchange are unprecedented. Such mobility has renewed social theorists' interest in linking transnational social space with cultural practice and identity formation. Kivisto writes about 'the necessity of groups producing their own social spaces as an integral aspect of group identity formation' (2003, p. 10). He then argues that exponentially intensified transnational connections could produce 'potentially new forms of social space' where recent immigrants orient and identify themselves in varied and unpredictable ways (Kivisto 2003, p. 10). This theoretical speculation may find an ideal case study in my research, which focuses on the transnational social space that Chinese dance occupies and transforms, and on the crucial connection between this space and immigrant identity construction. The production of Chinese dance in the US is embedded in transnational circuits: costumes and music are designed and made in China but used in the US; Chinese choreographers and professional dancers frequently travel between China and the US; immigrants in the US enjoy and learn Chinese dance through satellite TV, DVDs and YouTube. On the other hand, Chinese dance is also a practice that anchors and builds immigrant communities in place: spatially mobile, transnational networks do not trump immigrants' desire for a sense of belonging in their new home and a sense of connectedness to their places of origin they continue to call home. In looking at the paradoxical nature of immigrant identities, this research reveals some of 'the varied ways that immigrants orient themselves towards their homeland and their new settings', which Kivisto admitted 'we know little about' (2003, p. 16). ${ }^{4}$ 
I argue that to deepen our understanding of immigrants' collective identity formation and their orientation to the sending and receiving societies, we need to pay closer attention to their embodied cultural practices such as dance. I concur with anthropologists Henry, Magowan and Murray that 'dance practices be viewed as historically embodied, contextual, discursive and interconnected domains of lived experience' (2000 p. 253, emphasis added). To understand dance, we must explore its social, historical context. And we in turn achieve a better understanding of society and history thanks to the study of dance as lived experience and social processes. This is why so much scholarship has been produced in the last three decades on the relationship between dance and social categories such as gender, race, ethnicity, class and sexuality (Foster 1986; Hanna 1988; Adair 1992; Desmond 1995; Gaerlan 1999; Ram 2000a, 2000b, 2005; Chatterjea 2004; Farnell 2004; Manning 2004; Buckland 2006). In the context of international migration, dance has become many immigrants' lived experience, constituting their community experiences and identity formation. Ram (2000a, 2005), for example, investigates how recent immigrants from India negotiate their relationship with India, the immigrant community, and the dominant culture through engaging in South Indian dance in Australia. Gaerlan (1999) and San Juan (2001) write about the relationship between Filipino immigrants' variant dance practices (folkloric and ballroom) and their diaspora identity politics in the United States. Knudsen (2001) documents how Chilean immigrants foster their sense of belonging by doing traditional Chilean dance in Norway.

My research into Chinese dance practised by Chinese immigrants in the US contributes to this growing literature and illuminates the importance of embodied cultural practices for the social construction of ethnic identity. While digitally disseminated through transnational circuits, dance at its best must be produced and experienced with bodies in close proximity and in real time. It is perhaps for this reason that Chinese Dance Group is one of the most prominent institutions for Chinese immigrants in Midwest City. Compared to many other immigrant organizations in Midwest City (language schools, academies for acupuncture, professional associations and newspapers), dance organizations possess the unique capacity to bring a large number of immigrants into face-to-face interaction and generate a visceral sense of belonging and collective effervescence.

\section{Background}

Midwest City is a metropolitan area historically characterized by German, Irish and Scandinavian immigrant traditions and by statesanctioned Native American displacement. In the last forty years, this 
US metropolis has become a popular destination for refugees and immigrants from the global south, partly made possible by the 1965 Immigration Act that rescinded the national quota system instituted in the 1920s. Legal migration from mainland China was practically non-existent until the late 1970s due to prohibitive emigration policies in China and restrictive immigration laws in the US. In the 1990s, the first post-1965 wave of professional immigrants from China started raising families in Midwest City. These families and their young children provided vital energy and a raison d'être for Chinese Dance Group and other Chinese cultural organizations. CDG was established in 1992 by a Chinese American association when organizers of a municipal multicultural event dictated that organizations must provide entertainment in order to sell food. Four young Chinese American girls were summoned to dance. Thus began the eighteen years of CDG history.

In 2006, CDG reported having 250 students, mostly secondgeneration children and a dozen or so first-generation adults. Although most of the dancers are girls and women, men are frequently present. Ironically, the men provide leadership for $\mathrm{CDG}$, and, as expected, they handle 'men's work' such as making sets or transporting large props. Most of CDG's classes and performances are childrencentred, but the parents are crucial participants, paying tuition and costume fees (about 300 US dollars per child per year) and chauffeuring the children to and from their weekly dance lessons. Parents also volunteer to produce dance concerts, coordinate rehearsals, translate for non-English-speaking teachers and make costumes, sets and props. Such collective commitment has sustained five Chinese dance organizations in Midwest City since the early 1990s. CDG is the longest standing of these five groups, drawing audiences primarily from the Chinese immigrant community and secondarily from the public beyond the community.

\section{Methods}

I observed over 300 hours of CDG's dance classes, rehearsals and performances, as a dancer from 2000 to 2002, and as a CDG staff member from 2000 to 2001. From 2002 to 2003, I conducted in-depth interviews with twenty-two CDG members. I danced in or attended CDG's major dance productions from 2000 to 2010, and collected visual and textual documentation of these productions. My ethnographic work, emphasizing the dialogue between thick empirical observation and theoretical inquiries, has been influenced by grounded theories (Lofland and Lofland 1995) and extended case method (Burawoy et al. 1991). 


\section{Findings}

Chinese dance plays multiple roles in the construction of immigrant communities and identities. First and foremost, dance allows Chinese immigrants in the US to appropriate familiar cultural symbols in order to cultivate collective identities. The following writer, a former CDG board chair, emphasizes the role of dance in forging immigrant community cohesion:

We are a diverse group. In [this city] - by last count - are over ten Chinese organizations ... [F]ragmentation can ... sap from the Chinese diaspora the much-needed energy to move forward and be counted. ...

This year 2000, CDG's annual performance revolves around the magnificent dragon - a time-immemorial symbol of our Chinese culture and collective identity....[W]e as part of the Chinese diaspora yearn to experience a glimmer of our Eastern past that will awaken the shared identity and sense of connectedness without borders among us. (CDG programme 2000)

She makes it clear that Chinese dance, through its use of ancient symbols such as the dragon, can help galvanize an otherwise fragmented community. Earlier in the essay, she muses on the possible causes of such fragmentation:

The Chinese diaspora includes several generations of immigrants to America. At one end of the spectrum, we find some of our grandparents' generation living out their last days in decaying Chinatowns, forsaking their dreams of riches in America and facing the reality that they will never be able to return to their ancestral villages. At the other end of the spectrum, we have younger immigrants from Taiwan and China, doing their 'new-new thing' as cyberspace entrepreneurs and dreaming of initial public offerings ....

Elsewhere in this spectrum are those who fled oppression as ethnic Chinese minorities in S.E. Asia, families who escaped the civil wars of China, and still more fortunate others who came to the U.S. as 'foreign students.' Many continue to hold the passionate and bitter politics of their mother countries, and many find these conflicts divisive and futile. (CDG programme 2000)

This articulation of collective identity attests to the effect of circumstance in ethnic formation: if Chinese immigrants desire to 'move forward and be counted' as a political and economic force, they need to 'awaken the shared identity and senses of connectedness'. 
Does she presume an a priori but dormant collective identity that is inherently Chinese rooted in 'our Eastern past', thus claiming an essential, primordial identity? Or does she think that this shared identity needs to be constructed using existing cultural symbols such as the dragon? The answer is perhaps both. Recent Chinese immigrants frequently link their identities to primordial factors such as common ancestry (Kibria 2002); at the same time, they engage in the practice of reinventing collective identities that allow for group cohesion among Chinese immigrants of diverse national origins and ideological persuasions.

To illustrate these processes, I offer a close reading of CDG's 2000 production Descendants of the Dragon and their 2001 production Beloved Land, examining the ways in which CDG appropriates two particular symbols of primordial identity in constructing Chineseness in American society: the dragon and the homeland.

\section{Descendants of the Dragon (2000): constructing ancestry and community}

Chinese dance frequently deploys tropes such as the dragon and the homeland to invoke common ancestry and 'Chinese culture'. Dancers and audience were asked to sing in unison at the end of the $2000 \mathrm{CDG}$ production, 'We're all descendants of the dragon' (emphasis in the original). This melodramatic performance of kinship aptly ended a concert saturated with symbolic meanings.

The concert began with a portrayal of ancient China: immigrant dancers, both men and women in their late teens and early twenties (sleeveless tops and short skirts for female dancers; long pants and no tops for male dancers), marched on stage with totem props - deer, horse and fish - representing prehistoric ethnic groups in China. They then pieced parts of these totems together to construct the dragon. The act of putting the dragon together marked the constructed-ness of common ancestry and a reckoning of differences within. However, once the construction was completed, the dragon signified 'shared identity', not differences. The head of the dragon stayed as part of the backdrop throughout the show, which wove various Chinese mythologies to tell a story of love, loss and reunion in the context of agrarian China. The reunion took place in the mythical sphere where the dragon came alive. Or, could it be a village Spring Festival parade centred on a dragon dance? In either case, having taken on its own life, the dragon commanded homage: the finale of the evening's show included a rousing dragon dance performed by ten male dancers; children and women performers enacted fear, curiosity and eventually happy recognition of the dragon. The dragon is our ancestor now. 
A sense of collective effervescence was then invoked by the performative act of singing together.

Through these ritual-like spectacles that blurred the boundary between cultural performance (the dancing) and social performance (producing the concert and gathering to witness it) (Madison 2005), CDG embodied primordial identity based on common ancestry and reinforced the shared sense of being Chinese. CDG produced annual dance productions that lasted from one to two hours and ran for two to three days from 1995 to 2006 and from 2008 to 2012. Each production focused on a particular set of cultural symbols such as the dragon, the Chinese zodiac and the 3000 years of Chinese history.

CDG's commitment to keep these symbols alive is consistent with its mission of 'preserving and celebrating our Chinese cultural heritage' (CDG programme 2010). CDG's mission and practice exemplify what Kalpana Ram calls 'the existential crisis of migration - the need to "represent" one's culture to alien interlocutors as well as to transmit it to one's children' $(2005$, p. 130). Immigrants have to assimilate to, or at least engage with, the dominant culture and to maintain their cultural identities. In most cases, immigrants initiate cultural maintenance work because of their own desire for a sense of belonging and their own need to pass their heritage on to future generations. But, against the backdrop of multiculturalism in the US, immigrant communities also bear the burden to represent themselves as ethnic or exotic, which is often read by the dominant culture as 'other than American'. Let us not forget that the very conception of CDG in 1992 was due to the demand of the gatekeepers of a multicultural event: Chinese immigrants were not allowed to sell Chinese food there unless they agreed to do Chinese dance. Despite this awkward beginning, CDG is now a flourishing dance school/theatre that primarily serves the interest of the immigrant community. But it continues to participate in this citywide event every year and many other multicultural 'celebrations', representing 'Chinese culture' to predominantly white American audiences.

As Ram (2005) points out, these critical issues are rarely the immediate concerns of the immigrant community. More often than not, recent immigrants feel compelled to revisit familiar cultural symbols through dance because these symbols provide the immigrant 'an unstable and illusory impression of continuing to enjoy a grip on the world' (Ram 2005, p. 121). The transient feelings of being at home evoked by dance are important survival mechanisms for immigrants marginalized by American society. For example, after seeing a CDG Chinese New Year production, a Chinese immigrant wrote: 'If you are homesick during the holiday season, a perfect way to cheer up is to attend a Chinese dance concert' (Yi 2010). 
Chinese dance apparently offers sounds and sights that are cathartic for immigrant dancers and viewers. The production values (lighting, sets and design) of CDG's concerts play an important role in producing such effects. Frequently utilized in CDG's recent productions are elaborate sets, dramatic lighting, abundant dry ice and the digital projection of traditional Chinese art and scenery. In their 2009 production, CDG commissioned a local Chinese artist to produce traditional Chinese paintings the size of the entire backdrop. All this seems lavish for a community dance concert. But to recent Chinese immigrants the spectacle is an indispensable aspect of their experience of Chinese dance in a foreign environment. Since the 1980s, spectacular variety shows featuring singing, dancing and comedy skits are common events on national and provincial TV broadcast in China. When Chinese immigrants in the US try to emulate these shows, at work are not only their human and material resources circulating in the transnational social space, but also the embodied tastes and styles that the immigrants associate with their homeland and want to 'keep alive forever' (Ram 2005, p. 123).

\section{Beloved Land (2001): contesting nation and homeland}

Ram (2005) argues that immigrants who engage in dance practices originating from their homeland believe that culture and home could live on through dance. To entertain such an illusion is tantamount to reifying culture and home - to think or wish that they could remain fixed entities. Examining Chinese dance in transnational social spaces, I concur with Ram (2005) that culture and home are in fact socially constructed realities, and that dance plays an important role in their construction.

Through an analysis of CDG's 2001 production Beloved Land, I illustrate the constructed and contested nature of home and homeland, which are often conflated with a presumably unified Chinese nation. This particular production reveals that Chinese immigrants, through participating in Chinese dance, remain symbolically tethered to their home nation, as Chinese dance was a nationalistic project orchestrated by the Chinese state (Desmond 1995).

According to Louisa Schein (2000), Chinese nationalism manifests differently in different historical periods. At the beginning of the twentieth century, the Republican revolutionaries who overthrew the last imperial dynasty touted a notion of the Chinese nation that overtly excluded ethnic minorities and blatantly emphasized the superiority of Han, the majority ethnic group of China. By contrast, socialist nationbuilding since 1949 has paradoxically set out to celebrate and absorb ethnic differences with the not-so-hidden agenda of appropriating the natural and human resources of the areas populated by ethnic 
minorities. In this latter version of Chinese nationalism, Han superiority is implicit and paternalistic: the Chinese nation is compared to a big, harmonious family inclusive of all fifty-six ethnicities. One way in which ethnic minorities are incorporated into the Chinese nation is through state-sponsored documentation and categorization of ethnic languages and cultures, including dance.

As discussed earlier in this paper, appropriation of ethnic minority movement traditions has been an important aspect of the statesponsored institutionalization of 'Chinese dance' in China since the 1950s. Gaerlan (1999) documents similar appropriation of minority Muslim culture and dance by the modern Filipino state. As a result of this appropriation and paternalistic incorporation, ethnic dances, along with other facets of ethnic minority cultures, become objectified and fetishized in the dominant society (Schein 2000). Schein (2000) aptly names this process internal Orientalism as it mirrors how the West appropriates and objectifies non-Western cultures.

In the context of transnational migration, internal Orientalism is complicated by Orientalism in the West, which tends to erase all internal differences of the non-Western 'Other'. Chinese dance in China is a nationalistic construct subsuming ethnic cultures, but in China it remains important to distinguish the dances of different ethnic groups. After Chinese dance is transported to the US, however, the differences between ethnic groups in China are largely ignored by non-Chinese audiences. This disregard of subgroup differences is symptomatic of Orientalism and racialization (Cornell and Hartmann 2007) imposed upon immigrants, who certainly do not wish to be racialized as 'Orientals' who all look and sound alike. What do these immigrants intend when they perform Chinese dance, especially dances appropriated from ethnic minorities in China as in Beloved Land (2001)?

It is the mandate of Chinese nationalism that the dances of ethnic minorities be appropriated to represent the Chinese nation as a big, harmonious family inclusive of all ethnicities. Chinese immigrants within CDG have deployed the same strategy in their attempts to construct a nostalgic notion of homeland, on which their collective identity in American society hinges. The programme notes for Beloved Land (2001) open with a translated poem by its artistic director:

Far away in the East, there is a beloved land, her name is China In the bosom of that Beloved Land, cradles a quarter of humanity On that ancient soil of the Beloved Land, toil fifty-six ethnicities Deep from the heart of that Beloved Land, nourished by the wisdom of the ages.

(CDG programme 2001) 
The fifty-six ethnicities mentioned above include Tibetans and indigenous groups in Taiwan, consistent with China's official nationalistic discourse. The production featured a Tibetan dance and an indigenous Taiwanese dance, among other ethnic dances putatively originating from China. While Descendants of the Dragon (2000) showcased the masculine dragon as the symbol of peoplehood and obliterated the presence of all ethnic groups but Han, Beloved Land (2001) embodied Han Chinese nationalism through the gendered trope of a maternalistic, bosomed homeland that 'cradles' fifty-six ethnic offspring.

The fact that Chinese dance often embodies Han Chinese nationalism does not mean that immigrants intentionally put on a nationalistic display. The spectre of Chinese nationalism, however, came to haunt CDG in 2001. Shortly before CDG's production of Beloved Land in 2001, the Dalai Lama visited Midwest City. The group's artistic director, Wang, called an emergency meeting to make the following statements: 'We have heard some concern about us doing this Tibetan dance. But we'll do it anyway for two reasons: one, we're presenting Tibetan culture as beautiful; and two, there are small pockets of Tibetan population in China outside of Tibet' (Field notes 2001).

Claiming to represent Tibetan culture respectfully, Wang nonetheless dismissed the Tibetan perspectives. What would the Dalai Lama say? What would the Tibetans say? Her second argument asserted that the 'Tibetan' dance portrayed a minority group within the 'uncontroversial' parts of China. She and most members of CDG did not consider how segments of the Tibetan population ended up outside what is now considered Tibet nor did they consider the socioeconomic and political status of these small ethnic Tibetan communities within China's presumably uncontested territory. CDG attempted to divorce the notion of homeland from its contested politics only to reiterate the ideology of Han Chinese nationalism. What Wang said about the Tibetan dance and China-Tibet relations was a recitation of historical discourses that have underpinned China's domination of Tibet.

Such collective imagining of the Chinese nation and homeland has been occasionally challenged by CDG members of liminal status: they are active participants in the group's activities, but they are not considered Chinese by any means. In fact, from what I can gather, Kathy, a first-generation immigrant from Holland and an avid CDG participant, was probably the one who breached the silence on Tibet and thus instigated the social drama (Turner 1986) mentioned earlier. Here is her version of the story: 
Kathy: CDG says that it wants to represent the Chinese culture in the Midwest, and when I walked into the studio the very first time, I noticed a big map with all the pictures. And I was immediately looking for Tibet. And I saw that it was included in it, and I thought, 'That's wrong' (chuckles). And I thought, 'How can I ever get this across that I don't agree with it?'.... And then the Dalai Lama visited, and I wrote them a letter, and I explained that if he would walk into the studio, he probably wouldn't feel very good about seeing that. And I thought that if you're an immigrant, and you're in this country, you probably should acknowledge the fact that you know, we're having him over, and at least you should remove it or something. But then I never got a letter back, so I felt ... but I understand because it's all volunteer work. And I just wanted to let them know, and then I started a discussion once backstage with Leila [Chinese American] (chuckles).

Me: How did that go?

Kathy: Well it was very short, very sweet (laughs). She said, 'Oh no, it's all China. The history, thousands of years.' But I just couldn't say much anymore because we're starting the next dance. ... It was all so funny. ... I was actually helping set up the whole thing, especially the Tibetan dance. And I thought, 'Now look at me. I'm here, I'm feeling very weird and you know, conflicted about being in this group who's pretending that the Tibetans are just Chinese. And here is my daughter in this Tibetan dance.' (Interview 2002)

Kathy's chuckles and laughs can be read as signs of discomfort in bringing this topic up with me, a first-generation immigrant from mainland China. Probably not quite sure about where I stood on these issues, she had chosen to tell the story in a light-hearted way. Since CDG members hail from different nation-states, often with conflicting ideologies, crises that initiate social dramas like this can emerge. To circumvent these crises, CDG participants depoliticize dance and neutralize inherently political tropes such as the homeland, so that all Chinese diasporas can lay claim to these tropes and cultivate a shared sense of belonging.

In the spirit of neutrality, most dances on the programme of Beloved Land (2001) had nature themes (mountains, lotus, clouds, peacocks, fish and springtime). But the politics of dance became apparent when the dances depicting rituals of Chinese ethnic minorities unfolded. One 'ritual dance' involved a dozen barefoot Han women dancers thrashing their long, unbound hair, and then sitting on their folded knees repeatedly thrusting their chests forward to rhythmic drum beats. In another 'ethnic minority dance', 
a group of young Han female dancers entered the stage in a single file, with slow, contained bouncing steps and small circular hand gestures in front of their bellies. The drum beats got faster and the dancers kept up, with bigger and more vigorous movement. The dancers moved their arms and legs in circular motions throughout the dance, but, towards the end, the trajectories of their limbs were no longer contained. The dance ended with a frenzied mass of bodies twirling and jumping, accompanied by the dancers' highpitched hollering and fast, loud drum beats. Devoid of any historical context, these Han portrayals of ethnic minorities in China give the impression that these cultures are frozen in their premodern past.

CDG claims that Beloved Land (2001) celebrates the richness and diversity of 'Chinese culture'. This seems an innocuous statement, resonating not only with Han Chinese nationalism, but also with the dominant American multicultural ideology wherein differences are celebrated but power relations are not critiqued. Ironically, it is through fetishizing and appropriating ethnic minority cultures in China that Han Chinese immigrants of CDG manage to take part in American multicultural celebrations. Consistent with the spirit of such multicultural engagement, the programme brochure of Beloved Land (2001) is designed to educate, non-Chinese audiences in particular, as it is printed in English except for the Chinese original of the director's notes. Each of the sixteen ethnic groups 'represented' by the dances in the concert is introduced in one paragraph. Following is an excerpt from the paragraph about Yi, an ethnic group in Southwestern China:

In general, a Yi woman wears a coat trimmed with lace or embroidery with a long pleated skirt. The coat has buttons on the right and silver flowers on the collar. The bottom edge of the skirt is trimmed with layers of colorful striped cloth. A Yi woman covers her head with an embroidered square kerchief and often wears earrings. (CDG programme 2001)

Such detailed, voyeuristic portrayals of ethnic minorities make up the bulk of these introductory texts, describing their geographic locations, religious beliefs, housing styles, rites of passages and so on. But Han the dominant ethnicity in China - is introduced in a very different manner:

Over ninety percent of China's 1.2 billion people are members of the Han clan. As the majority population, their history and culture goes [sic] back 3,000 years. Due to their vast geographic area and history, 
it is a challenge to summarize their traditions and customs. (CDG programme 2001)

The Han culture is thus considered too complex and 'vast' to be captured in one paragraph. It is also the only group explicitly associated with temporality $-3,000$ years of history. Never mind that a history of conquest implicates the colonized minorities as well as the victorious colonizer - Han Chinese in most of Chinese history. The contrast between the description of Han as normative, historical and multifaceted and the depiction of ethnic minorities as exotic, timeless and one-dimensional implies a power relationship characteristic of Han Chinese nationalism: only against the putative 'primitiveness' and exoticness of ethnic minorities can the Han-dominated Chinese nation proclaim itself modern (Schein 2000).

The relationship between the Chinese nation and ethnic minorities in China, as well as colonized Tibet, eerily mirrors the relationship between the American nation and ethnic minorities in the US, including Chinese immigrants (Winant 2001). Many Han Chinese immigrants, having experienced marginalization in American mainstream institutions, recognize their subordinate status in American society. A CDG dancer who is an information technology professional confessed, 'When I dance at CDG, I feel that I belong. Anywhere else, at work, or dealing with clients, I know very well that this is not my place' (Interview notes 2002). But few Han immigrants are aware that ethnic oppression mars their home nation also and that Chinese dance serves as an ideological apparatus for the Chinese nation-state (Interview notes 2002). Chinese immigrants appropriate Chinese dance and, along with it, the cultures of ethnic minorities in China to construct identities and communities in the US and to conform to the US multicultural ideology. Just as Chinese dance retains its ideological residue of Han Chinese nationalism, recent immigrants do not completely shed their identity as Chinese nationals: while growing into a newly constructed ethnic identity, they are not capable of a clean break from the homeland, albeit a social construct in itself.

Transnational social spaces could potentially work to strengthen immigrants' primordial ties to their homeland, which are now sustained through more frequent air travel, sophisticated communications technologies and the sending countries' governments' intent to foster positive relationship with their resource-rich emigrants. 'One yearns for loved ones even more during the holiday seasons. Nothing but a dance concert like this can cheer up the homesick overseas Chinese' (Yi 2010). China Tribune, a local Chinese newspaper in Midwest City, printed this above audience review of a locally produced Chinese dance concert next to a news item about the international touring of Chinese song and dance troupes during the 2010 Chinese 
New Year season, sponsored by the Chinese State Department. This juxtaposition is uncanny and yet meaningful: Chinese immigrants who enjoy locally produced Chinese dance are also aware of the Chinese government's use of music and dance as a way of connecting with overseas Chinese. ${ }^{5}$ As Yi indicates, however, the locally produced concerts are ultimately more interesting because 'you actually know the people on stage: family members, neighbors, colleagues and friends', and because 'the fun is in the participation' (2010, p. A14). Both the locally produced immigrant dance and the state-sponsored Chinese dance occupy and constitute the transnational social space, in which immigrants re-define identities and communities in their host society and re-orient themselves to their homeland.

\section{Conclusion}

My readings of CDG's dance productions Descendants of the Dragon (2000) and Beloved Land (2001) and the surrounding discourses suggest that the primordial contents of ethnicity such as ancestry and homeland are indeed socially constructed. These 'constructed primordials' in turn shape immigrant identities and communities, as they evoke deep-seated emotions. Considering how Chinese dance is charged with cultural and historical meanings, one should not be surprised that immigrants seize on dance as an embodied tool for collective identity construction.

Although immigrants and their host societies tend to see dance as an apolitical activity, politics is an inherent aspect of cultural production and practices. When Chinese immigrants produce a dance concert, they have to negotiate the politics of representation: 'What kinds of stories should we tell? How should we tell the stories? How do we represent ourselves in ways that maintain our cultural identity and are acceptable in American society?' It does not matter if the immigrants are unaware of the politics behind these decisions. The fact that dance-making Chinese immigrants obliviously reiterate Han majority privilege associated with Han Chinese nationalism only attests to the insidious workings of this far-reaching ideology. Now that they are themselves considered an ethnic minority in the US, recent Han Chinese immigrants have to contend with a different kind of politics where their own cultural identities are no longer normative and dominant, and where they become the 'Other' against which white American national identity is defined. Making Chinese dance in the US, much like making identity claims, is a political act.

My research highlights the roles of Chinese dance in constructing immigrant communities and identities. It has shown that dance, a transnational cultural practice, constitutes an embodied site of identity formation among recent Chinese immigrants. Both the cultural 
performance of dance and social performance surrounding dance serve to reiterate and reproduce what is important for the community: being in each other's presence and appreciating embodied aesthetics evoking 'home'. Close readings of immigrant dance productions also allow for a much needed critique of the reified notions of ancestry, kinship and home.

With attention to embodied cultural practices, this research engages with different paradigms of ethnicity. Circumstantialism is at work when immigrants of diverse backgrounds claim shared Chinese-ness in order to form a community that potentially wields more power and mobilizes more resources. Presumed common ancestry and kinship 'constructed primordials' - are instrumental in Chinese immigrants' effort to build community and collective identity. Explicating how immigrants reconstruct symbols of ancestry and kinship via dance in the transnational social space, my research offers a case study of the constructionist view of ethnicity.

Last but not least, the production of Chinese dance, facilitated by transnational circuits of goods, service and ideas, paradoxically contributes to the building of a place-bound immigrant community. The concept of liminality that characterizes both dance/performance spaces and migration helps us understand immigrant identities in transnational contexts. Immigrants are caught (or move) in between two nations, whose economic and political realities are increasingly intertwined. Being mobile in transnational spaces entails living with ambiguities and paradoxes. Immigrant identities are constructed through embodied cultural practices and yet often understood as primordial, transnational and yet necessarily place-bound. It is quite an intricate dance that immigrants do, weaving identities, cultures and homes between continents and across oceans.

\section{Notes}

1. Midwest City is a fictitious name.

2. A popular Chinese grocery store in Midwest City released all their employees so they could go home and watch the ceremony on TV.

3. Chinese Dance Group is a fictitious name. It is referred to as CDG hereafter.

4. Kivisto (2003) points out the lack of research on this topic except for Levitt's Transnational Villagers (2001). As he wrote, however, research on immigrants' transnational practice has gained much momentum, culminating in a special issue of International Migration Review entitled 'International Perspectives on Transnational Migration' (2003). The debate about the very term transnationalism has not generated a theoretical consensus (Foner 1997; Waldinger and Fitzgerald 2004), but it has produced much empirical research focusing on different aspects of contemporary immigrants' ties to their homelands (Levitt, DeWind and Vertovec 2003; Portes 2003).

5. It would be interesting to investigate when and why the Chinese government started sponsoring these cultural outreach troupes to overseas Chinese. But this topic is beyond the scope of this paper. 


\section{References}

ADAIR, CHRISTY 1992 Woman and Dance: Sylphs and Sirens, New York: New York University Press

APPADURAI, ARJUN 1996 Modernity at Large: Cultural Dimensions of Globalization, Minneapolis, MN: University of Minneapolis Press

BUCKLAND, THERESA J. 2006 Dancing from Past to Present: Nation, Culture, Identities, Madison, WI: University of Wisconsin Press

BURAWOY, MICHAEL et al. 1991 Ethnography Unbound: Power and Resistance in the Modern Metropolis, Berkeley, CA: University of California Press

CERULO, KAREN 1997 'Identity construction: new issues, new directions', Annual Review of Sociology, vol. 23, pp. 385-409

CHATTERJEA, ANANYA 2004 Butting Out! Reading Cultural Politics in the Works by Jawole Willa Jo Zollar and Chandralekha, Middletown, CT: Wesleyan University Press CORNELL, STEPHEN and HARTMANN, DOUGLAS 2007 Ethnicity and Race: Making Identities in a Changing World, 2nd edn, Thousand Oaks, CA: Pine Forge Press

DESMOND, JANE (ed.) 1995 Meaning in Motion: New Cultural Studies of Dance, Durham, NC: Duke University Press

FAIST, THOMAS 2000a The Volume and Dynamics of International Migration and Transnational Social Spaces, Oxford: Oxford University Press

2000b 'Transnationalization in international migration: implications for the study of citizenship and culture', Ethnic and Racial Studies, vol. 23, no. 2, pp. 189-222

FARNELL, BRENDA 2004 'The fancy dance of racializing discourse', Journal of Sport and Social Issues, vol. 28, pp. 30-55

FEATHERSTONE, MIKE 1996 'Localism, globalism, and cultural identity', in Rob Wilson and Wilmal Dissanayake (eds), GloballLocal: Cultural Production and the Transnational Imaginary, Durham, NC: Duke University Press, pp. 46-77

FONER, NANCY 1997 'What's new about transnationalism? New York's immigrants today and at the turn of the century', Diaspora, vol. 6, no. 3, pp. 355-75

FOSTER, SUSAN 1986 Reading Dancing: Bodies and Subjects in Contemporary American Dance, Berkeley, CA: University of California Press

GAERLAN, BARBARA 1999 'In the court of the sultan: Orientalism, nationalism, and modernity in Philippine and Filipino American dance', Journal of Asian American Studies, October, pp. 251-87

HANNA, JUDITH L. 1988 Dance, Sex, and Gender: Signs of Identity, Dominance, Defiance, and Desire, Chicago, IL, and London: University of Chicago Press

HENRY, ROSITA, MAGOWAN, FIONA and MURRAY, DAVID 2000 'Introduction', The Australian Journal of Anthropology, vol. 11, no. 3, pp. 253-60

KIBRIA, NAZLI 2002 'Of blood, belonging, and homeland trips: transnationalism and identity among second-generation Chinese and Korean Americans', in Peggy Levitt and Mary Waters (eds), The Changing Face of Home: The Transnational Lives of the Second Generation, New York: Russell Sage Foundation, pp. 295-311

KIVISTO, PETER 2001 'Theorizing transnational immigration: a critical review of current efforts', Ethnic and Racial Studies, vol. 24, no. 4, pp. 549-77

2003 'Social spaces, transnational immigrant communities, and the politics of incorporation', Ethnicities, vol. 3, no. 1, pp. 5-28

KNUDSEN, JAN S. 2001 'Dancing cueca "with your coat on": the role of traditional Chilean dance in an immigrant community', British Journal of Ethnomusicology, vol. 10, no. 2, pp. 61-83

LEVITT, PEGGY 2001 Transnational Villagers, Berkeley, CA: University of California Press LEVITT, PEGGY and WATERS, MARY (eds) 2002 The Changing Face of Home: The Transnational Lives of the Second Generation, New York: Russell Sage Foundation 


\section{Hui Wilcox}

LEVITT, PEGGY, DEWIND, JOSH and VERTOVEC, STEVEN 2003 'International perspectives on transnational migration: an introduction', International Migration Review, vol. 37 , no. 3 , pp. $565-75$

LOFLAND, JOHN and LOFLAND, LYN H. 1995 Analyzing Social Settings: A Guide to Qualitative Observation and Analysis, 3rd edn, London: Wadsworth

LOUIE, ANDREA 2002 'Creating histories for the present: second-generation (re)definitions of Chinese American culture', in Peggy Levitt and Mary Waters (eds), The Changing Face of Home: The Transnational Lives of the Second Generation, New York: Russell Sage Foundation, pp. $312-40$

MADISON, D. SOYINI 2005 Critical Ethnography, Thousand Oaks, CA: Sage

MANNING, SUSAN 2004 Modern Dance, Negro Dance: Race in Motion, Minneapolis, MN: University of Minnesota Press.

NAGEL, JOANNE 1994 'Constructing ethnicity: creating and recreating ethnic identity and culture', Social Problems, vol. 41, no. 1, pp. 152-76

ONG, AIHWA 1999 Flexible Citizenship: The Cultural Logics of Transnationality, Durham, NC: Duke University Press

PORTES, ALEJANDRO 2003 'Conclusion: theoretical convergences and empirical evidence in the study of immigrant transnationalism', International Migration Review, vol. 37, no. 3, pp. 874-92

RAM, KALPANA 2000a 'Dancing the past into life: the rasa, nrtta, and raga of immigrant existence', The Australian Journal of Anthropology, vol. 11, no. 3, pp. 261-73

$2000 \mathrm{~b}$ 'Listening to the call of dance: re-thinking authenticity and essentialism', The Australian Journal of Anthropology, vol. 11, no. 3, pp. 358-64

2005 'Phantom limbs: South Indian dance and immigrant reification of the female body', Journal of Intercultural Studies, vol. 26, no. 1-2, pp. 121-37

SANDERS, JIMY 2002 'Ethnic boundaries and identity in plural societies', Annual Review of Sociology, vol. 28, pp. 327-57

SAN JUAN, CAROLINA 2001 'Ballroom dance as an indicator of immigrant identity in the Filipino community', Journal of American and Comparative Cultures, vol. 24, no. 3-4, pp. 177-81

SCHEIN, LOUISA 2000 Minority Rules: The Miao and the Feminine in China's Cultural Politics, Durham, NC: Duke University Press

SOLLORS, WERNER (ed.) 1989 The Invention of Ethnicity, Oxford: Oxford University Press

TURNER, VICTOR 1986 The Anthropology of Performance, New York: Performing Arts Journal

WALDINGER, ROGER and FITZGERALD, DAVID 2004 'Transnationalism in question', The American Journal of Sociology, vol. 109, no. 5, pp. 1177-95

WATERS, MARY 1990 Ethnic Options: Choosing Identities in America, Berkeley, CA: University of California Press

WINANT, HOWARD 2001 The World is a Ghetto: Race and Democracy since World War II, New York: Basic Books

YI, XI 2010 'Drums, dances and the Year of Tiger', China Tribune, 29 January

HUI WILCOX is Associate Professor in the Department of Sociology at St. Catherine University.

ADDRESS: 4051, Department of Sociology, St. Catherine University, 2004 Randolph Avenue, St. Paul, MN 55105, USA.

Email: hnwilcox@stkate.edu 